\title{
Soil water energetic status and cowpea beans irrigated with saline water
}

\author{
Wanderson J. de Oliveira ${ }^{1}$, Edivan R. de Souza ${ }^{2}$, Brivaldo G. de Almeida ${ }^{2}$, \\ Ênio F. de F. e Silva' ${ }^{1}$, Hidelblandi F. de Melo $^{2} \&$ Lucas Y. C. Leal ${ }^{3}$ \\ ${ }^{1}$ Universidade Federal Rural de Pernambuco/Departamento de Engenharia Agrícola/Programa de Pós-graduação em Engenharia Agrícola, Recife, \\ PE. E-mail: w.joliveira@yahoo.com.br; enio.fsilva@ufrpe.br \\ ${ }^{2}$ Universidade Federal Rural de Pernambuco/Departamento de Agronomia/Programa de Pós-graduação em Ciências do Solo, Recife, PE. E-mail: \\ edivan.rodrigues@ufrpe.br (Corresponding author); brivaldoalmeida@gmail.com; hidelfarias@gmail.com \\ ${ }^{3}$ Universidade Federal Rural de Pernambuco/Departamento de Engenharia Agrícola, Recife, PE. E-mail: lucasyago1@hotmail.com
}

Key words:

water potential

osmotic potential

Vigna unguiculata

\begin{abstract}
A B S T R A C T
The study of the water energetic status under saline condition and its impact on the development of cowpea is of extreme importance, since this crop is the food base in many parts of the world. An experiment was carried out in a greenhouse from March to May 2014 using the cultivar IPA 206 in Fluvisol collected in the municipality of Pesqueira, PE, Brazil. Waters with six levels of electrical conductivity $\left(0 ; 2.5 ; 5 ; 7.5 ; 10 ; 12.5 \mathrm{dS} \mathrm{m}^{-1}\right)$ formulated with $\mathrm{NaCl}$ and a salt mixture were used. The experiment was conducted in randomized blocks in a $6 \times 2$ factorial arrangement with four replicates, forming 48 experimental plots. The matric, osmotic and total potential of water in the soil, the osmotic, and water potential in the plant and atmospheric potential were determined. Plant and soil osmotic potentials decreased with the increase in irrigation water electrical conductivity, which contributed to the decrease in plant water potential. There was no significant difference between the salts used in the composition of the irrigation water for the potentials evaluated in the soil and in the plant; there was no equilibrium between soil and plant water potentials at predawn.
\end{abstract}

\section{Palavras-chave:} potencial hídrico potencial osmótico Vigna unguiculata

\section{Estado energético da água do solo e feijão-caupi irrigado com água salina}

\begin{abstract}
R E S U M O
O estudo do estado energético da água sob condição de salinidade e seu impacto sobre o desenvolvimento do feijão-caupi são de extrema importância visto que esta cultura é, em grande parte do mundo, a base alimentar. Experimento em casa de vegetação foi desenvolvido de março a maio de 2014 utilizando-se a cultivar de feijão-caupi IPA 206 em Neossolo Flúvico coletado no município de Pesqueira, PE. Foram utilizadas águas com seis níveis de condutividade elétrica $\left(0 ; 2,5 ; 5 ; 7,5 ; 10 ; 12,5 \mathrm{dS} \mathrm{m}^{-1}\right)$ formuladas a partir de $\mathrm{NaCl}$ e de uma mistura de sais, semelhante à água de um poço do local de coleta do solo. $\mathrm{O}$ experimento foi conduzido em blocos ao acaso em arranjo fatorial 6 x 2 com 4 repetições totalizando 48 unidades experimentais. Determinaram-se os potenciais matricial, osmótico e total do solo; osmótico e hídrico da planta e o potencial da atmosfera. Os potenciais osmóticos na planta e no solo diminuíram com o aumento da condutividade elétrica da água o que contribuiu também para a redução do potencial total na planta. Não houve diferença significativa entre as fontes de água na composição da água de irrigação para os potenciais avaliados no solo e na planta; não ocorreu equilíbrio entre os potencias hídricos do solo nem da planta antes do amanhecer.
\end{abstract}




\section{INTRODUCTION}

Soil salinity is considered as one of the environmental factors that most limit crop development and yield, and occurs in more than 100 countries (Rengasamy, 2006; Lv et al., 2012), becoming a problem especially in arid and semiarid regions worldwide, which are susceptible to this process because of the conditions of low rainfall and high balance of solar energy available to the evaporation process.

The use of saline water or the cultivation in already salinized soils causes yield loss in the crops and has become a common problem in the world, because most cultivated plants are glycophytes and, therefore, sensitive to salinity (Adolf et al., 2013).

Various crops have been evaluated when cultivated under the effect of saline stress. Cowpea (Vigna unguiculata (L.) Walp.) is one of these crops and is classified as moderately sensitive to salinity (Grieve et al., 2012), although it has cultivars developed to increase its tolerance to saline stress, such as IPA 206, classified as moderately tolerant to salinity (Dantas et al., 2002).

IPA 206, a cultivar developed at the Agricultural Research Institute of Pernambuco-IPA-PE, is widely used due to its tolerance to water and saline stress conditions, as well as in soils with low fertility (Nascimento et al., 2011).

According to Ayers \& Westcot (1999), the threshold value of electrical conductivity for the normal development of cowpea is $3.3 \mathrm{dS} \mathrm{m}^{-1}$ in the irrigation water and $1.3 \mathrm{dS} \mathrm{m}^{-1}$ in the saturation extract. Souza et al. (2011), cultivating cowpea under saline stress, and Coelho et al. (2013), using a mixture of $\mathrm{NaCl}$ and $\mathrm{CaCl}_{2}$, with $0,4,8$ and $12 \mathrm{dS} \mathrm{m}^{-1}$, cultivated cowpea under saline stress and found physiological alterations during the development of the crop.

Salinity effects on the soil and on the plant are better evaluated when one studies the behavior of the water potentials involved in the soil-plant-atmosphere system in order to obtain information about the movement and availability of water in these environments. Many studies can be found in the literature associating salinity with water potentials (Souza et al., 2012; Adolf et al., 2013; Coelho et al., 2013; Souza et al., 2014). In addition, the evaluation of the influence of the type of salt in the irrigation water is of great relevance in studies on salinity in the soil-plant system (Melo et al., 2016).

Due to the socioeconomic importance of the bean crop and the advance of salinity in various regions of the world, this study aimed to evaluate the effects of salinity on the cowpea crop (IPA 206) cultivated with saline water at increasing salt concentrations $\left(0 ; 2.5 ; 5 ; 7.5 ; 10\right.$ and $\left.12.5 \mathrm{dS} \mathrm{m}^{-1}\right)$ prepared with $\mathrm{NaCl}$ and with a mixture of salts similar to the field conditions, as well as the energetic state of the water in the soil-plantatmosphere system.

\section{Material ANd Methods}

The study was carried out in a greenhouse at the Federal Rural University of Pernambuco-UFRPE (08 00' 59.9”' S; 34 56 $38.6^{\prime} \mathrm{W}$ ) from March to May 2014, totaling 60 days of evaluation.

The experiment was conducted in randomized blocks with 4 replicates in a $6 \times 2$ factorial scheme, corresponding to six levels of electrical conductivity and two sources of water.

The soil material used in the experiment was collected in the municipality of Pesqueira, PE, Brazil, in the layer of $0-30 \mathrm{~cm}$ and classified as Fluvic Neosol (EMBRAPA, 2013), without problems of salinity and sodicity. Then, the soil was air-dried, pounded to break up clods, homogenized and sieved through a 4-mm mesh.

Soil chemical characterization, using air-dried fine earth (ADFE), was performed through the determination of exchangeable cations $\left(\mathrm{Ca}^{2+}, \mathrm{Mg}^{2+}, \mathrm{Na}^{+}\right.$and $\mathrm{K}^{+}$) (Thomas, 1982); saturation extract was obtained through the preparation of saturation paste (Richards, 1954), when electrical conductivity, soluble bases and the chloride ion were determined (EMBRAPA, 1997). The values of sum of bases (SB) and exchangeable sodium percentage (ESP) were calculated based on the obtained results of the exchange complex.

In the saturation extract, the soil showed $\mathrm{Ca}^{2+}(1.00 \mathrm{mmol}$ $\left.\mathrm{L}^{-1}\right), \mathrm{Mg}^{2+}\left(1.04 \mathrm{mmol} \mathrm{L}_{\mathrm{c}}^{-1}\right), \mathrm{Na}^{+}\left(5.34 \mathrm{mmol} \mathrm{L}_{\mathrm{c}}^{-1}\right), \mathrm{K}^{+}(1.12 \mathrm{mmol}$ $\left.\mathrm{L}^{-1}\right)$ and $\mathrm{Cl}\left(6.80 \mathrm{mmol}_{\mathrm{c}} \mathrm{L}^{-1}\right), \mathrm{EC}\left(0.99 \mathrm{dS} \mathrm{m}^{-1}\right)$ and $\mathrm{pH}_{(1: 2.5)} 8.71$, and in the sorption complex, $\mathrm{Ca}^{2+}\left(5.53 \mathrm{cmol}_{\mathrm{c}} \mathrm{kg}^{-1}\right), \mathrm{Mg}^{2+}(2.22$ $\left.\mathrm{cmol}_{\mathrm{c}} \mathrm{kg}^{-1}\right), \mathrm{Na}^{+}\left(0.26 \mathrm{cmol}_{\mathrm{c}} \mathrm{kg}^{-1}\right), \mathrm{K}^{+}\left(0.5 \mathrm{cmol}_{\mathrm{c}} \mathrm{kg}^{-1}\right), \mathrm{SB}(8.51$ $\left.\mathrm{cmol}_{\mathrm{c}} \mathrm{kg}^{-1}\right)$, ESP (3\%) and $\mathrm{pH}_{(1: 2.5)} 7.7$.

Physical characterization was performed according to the methodology of EMBRAPA (1997). The soil showed fine sand (312 $\left.\mathrm{g} \mathrm{kg}^{-1}\right)$, coarse sand $\left(117 \mathrm{~g} \mathrm{~kg}^{-1}\right)$, silt $\left(422 \mathrm{~g} \mathrm{~kg}^{-1}\right)$, clay $\left(149 \mathrm{~g} \mathrm{~kg}^{-1}\right)$, clay dispersed in water $\left(102 \mathrm{~g} \mathrm{~kg}^{-1}\right)$, soil bulk density $\left(1.24 \mathrm{~kg} \mathrm{dm}^{-3}\right)$, soil particle density $\left(2.52 \mathrm{~kg} \mathrm{dm}^{-3}\right)$, total porosity (50.79\%), field capacity $\left(0.24 \mathrm{~kg} \mathrm{~kg}^{-1}\right)$ and permanent wilting point $\left(0.05 \mathrm{~kg} \mathrm{~kg}^{-1}\right)$.

Cowpea plants (cultivar IPA 206) were cultivated in pots with capacity for $6 \mathrm{~L}$, filled with the soil material.

Before planting cowpea seeds, the pot was irrigated in order to have a moisture content corresponding to $80 \%$ of its capacity $\left(0.18 \mathrm{~g} \mathrm{~g}^{-1}\right)$. Each plot was formed by one pot with soil and two plants.

The soil was irrigated using waters with electrical conductivities of $0 ; 2.5 ; 5.0 ; 7.5 ; 10.0$ and $12.5 \mathrm{dS} \mathrm{m}^{-1}$, prepared using $\mathrm{NaCl}$ and a mixture of $\mathrm{Ca}, \mathrm{Mg}, \mathrm{Na}, \mathrm{K}$ and chloride, in a 6 $\mathrm{x} 2$ factorial scheme, simulating the composition found in the water wells of the region of Pesqueira, PE (Table 1).

Table 1. Required amounts of salt $\left(\mathrm{g} \mathrm{L}^{-1}\right)$ to obtain the electrical conductivity values used for both sources of water and the osmotic potential of the solutions ( $\Psi_{0}$, in $\left.\mathrm{MPa}\right)$

\begin{tabular}{|c|c|c|c|c|c|c|c|c|}
\hline \multirow{3}{*}{$\begin{array}{c}E C \\
\mathrm{dS} \mathrm{m}^{-1}\end{array}$} & \multicolumn{8}{|c|}{ Water sources } \\
\hline & \multicolumn{2}{|c|}{ Sodium chloride } & \multicolumn{6}{|c|}{ Mixture of salts } \\
\hline & $\mathrm{NaCl}$ & $\Psi_{0}$ & $\mathrm{NaCl}$ & $\mathrm{KCl}$ & $\mathrm{MgCl}_{2}$ & $\mathrm{CaCl}_{2}$ & Total & $\Psi_{0}$ \\
\hline 0 & 0 & 0 & 0 & 0 & 0 & 0 & 0 & 0 \\
\hline 2.5 & 1.3600 & -0.1044 & 1.0510 & 0.0050 & 0.3060 & 0.2440 & 1.6060 & -0.1171 \\
\hline 5.0 & 2.9060 & -0.2227 & 1.9900 & 0.0130 & 0.5560 & 0.4430 & 3.0020 & -0.2334 \\
\hline 7.5 & 4.6690 & -0.3578 & 3.2010 & 0.0160 & 0.8860 & 0.6930 & 4.7960 & -0.3458 \\
\hline 10.0 & 6.6500 & -0.5096 & 4.6500 & 0.0270 & 1.2970 & 1.0060 & 6.9800 & -0.5382 \\
\hline
\end{tabular}


In order to meet the nutritional requirements of the crop, fertilization was performed according to the Manual of Recommendation of Fertilization (IPA, 2008).

Irrigation was performed at the end of the day, by replenishing the water lost through evapotranspiration, measured using a digital balance. Distilled water was used during the first seven days and, from the eighth day on, water with increasing EC values was used in order not to cause osmotic shock. Thus, all pots were equilibrated with the EC values corresponding to the treatments at 16 days after planting (DAP).

At 35 DAP, in the early hours, from 3 to 4 a.m. (before sunrise, a condition called predawn), the water potential $\left(\Psi_{t}\right)$ of the plant was determined using the Scholander pressure chamber (model 1515D Pressure Chamber Instrument - PMS Instrument Company).

The osmotic potential $\left(\Psi_{0}\right)$ of the plants was determined using the same leaf in which the water potential was determined; this leaf was involved in aluminum paper and stored in a freezer at $-20^{\circ} \mathrm{C}$. In the processing, the leaves were macerated under liquid nitrogen and filtered.

The sap was placed in appropriate tubes and centrifuged at $10,000 \mathrm{rpm}$ for $10 \mathrm{~min}$ at $4{ }^{\circ} \mathrm{C}$. The supernetant solution was collected and osmolity was determined in an osmometer (Vapro Wescor Model 5600).

Osmotic potential was estimated through the application of the Van't Hoff Eq. 1:

$$
\Psi_{\mathrm{o}}=-\mathrm{R} \cdot \mathrm{T} \cdot \mathrm{C}
$$

where:

$$
\begin{aligned}
& \Psi_{\mathrm{o}} \quad \text { - estimated osmotic potential of the plants, } \mathrm{MPa} \text {; } \\
& \mathrm{R} \text { - universal gas constant, } 0.0082 \mathrm{~kg} \mathrm{MPa} \mathrm{mol}^{-1} \mathrm{~K}^{-1} \text {; } \\
& \mathrm{T}
\end{aligned}
$$

At collection and before freezing the leaves used for osmotic potential determination, leaf discs with standardized size (diameter $=7.62 \mathrm{~mm}$ ) were removed for the determination of Relative Water Content (RWC), calculated through Eq. 2.

$$
\mathrm{RWC}=\left[\frac{(\mathrm{FMW}-\mathrm{DMW})}{(\mathrm{TMW}-\mathrm{DMW})}\right] 100
$$

where:

RWC - relative water content in the leaves, \%;

FMW - fresh matter weight, mass unit;

DMW - dry matter weight, mass unit; and,

TMW - turgid mass weight, mass unit.

The total water potential in the soil $\left(\Psi_{t}\right)$ was determined at 35 DAP, obtained through the sum of its components. For this, during the predawn hours of the day, a soil sample was collected for moisture determination and the matric potential was estimated using the soil water retention curve. For the determination of soil osmotic potential, the soil solution was collected in the same day, using an extracting capsule and its osmolality was determined through vapor pressure osmometer, while the soil osmotic potential was estimated through the Van't Hoff equation. Soil water potential was obtained through the sum of the matric, osmotic and gravitational potentials (considering the depth of $30 \mathrm{~cm}$ in the pot as a reference).

As the last component of the soil-plant-atmosphere system, the water potential in the atmosphere was calculated as a function of the relative air humidity and temperature (Slatyer, 1967) Eq. 3.

$$
\Psi \mathrm{a}=\left(-\frac{\mathrm{RT}}{\mathrm{Va}}\right) \ln \left(\frac{\mathrm{ea}}{\mathrm{es}}\right)
$$

where:

$$
\begin{array}{ll}
\Psi \mathrm{a} & \text { - water potential in the atmosphere, } \mathrm{MPa} ; \\
\mathrm{R} & \text { - universal gas constant, } 0.0082 \mathrm{~L} \mathrm{MPa} \mathrm{mol}^{-1} \mathrm{~K}^{-1} \text {; } \\
\mathrm{T} & \text { - temperature, } \mathrm{K} \text {; } \\
\mathrm{Va} & \text { - partial molar volume of water, } 0.018 \mathrm{~L} \mathrm{~mol}^{-1} \text {; } \\
\mathrm{ea} & \text { - partial vapor pressure in the air, } \mathrm{MPa} \text {; and, } \\
\mathrm{es} & \text { - partial vapor pressure at saturation, } \mathrm{MPa} \text {. }
\end{array}
$$

The measurements of temperature and relative air humidity were performed every $15 \mathrm{~min}$ during the experimental period, with a HOBO U12-012 data logger.

Plant height was measured using a measuring tape at 38 DAP; at the end of the experiment, the plant was collected and separated into leaves, stem and roots, weighed and dried in a forced-air over at $65{ }^{\circ} \mathrm{C}$. From 38 to $60 \mathrm{DAP}$, the pods were collected and crop yield was determined.

Statistical evaluation consisted of analysis of variance, adjustment of regression model for the salinity levels and test of comparison of means for the water sources.

\section{Results AND Discussion}

The increase in the concentration of salts in the soil solution reduced the osmotic potential and, consequently, the total water potential in the soil. The total potential of the soil decreased by about $190 \%$, from $-0.34 \mathrm{MPa}$ in the control treatment $\left(0 \mathrm{dS} \mathrm{m}^{-1}\right)$ to $-0.98 \mathrm{MPa}$ in the treatment with $\mathrm{EC}$ of $12.5 \mathrm{dS} \mathrm{m}^{-1}$ (Figure 1).

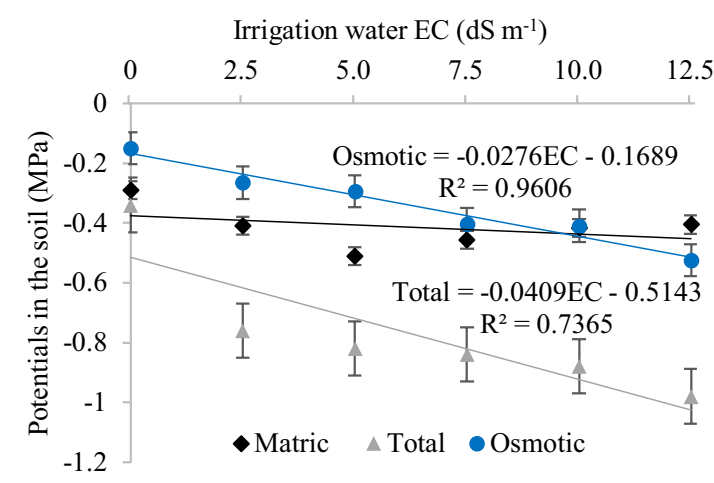

Matric potential CV\% = 36.62; Osmotic potential CV\% = 19.12; Total potential CV\% $=17.56$ Figure 1. Matric, osmotic and total potentials in the soil with their respective standard errors as a function of the electrical conductivity in the irrigation water (EC) at 35 days after planting, determined in the predawn hours 
Similar results were found by other authors, such as Razzaghi et al. (2011), who observed that soil water potential also decreased with the increment in salinity, and Coelho et al. (2014), who cultivated cowpea under different EC values and observed reduction of the osmotic potential in a sandy loam Neosol and in a clay loam Neosol.

There was no significant difference between the sources of water for the osmotic potential in the plant $(P>0.05)$, corroborating Gómez-Bellot et al. (2013), who also did not find significant difference between the types of irrigation water with respect to the osmotic potential in the plant, using a solution of $\mathrm{NaCl}\left(4 \mathrm{dS} \mathrm{m}^{-1}\right)$ and wastewater $\left(4 \mathrm{dS} \mathrm{m}^{-1}\right)$ in the irrigation of Euonymus and Laurustinus plants.

Plant osmotic potential decreased linearly with the increase in EC; the EC of $0 \mathrm{dS} \mathrm{m} \mathrm{m}^{-1}$ led to the highest value of osmotic potential, corresponding to $-0.58 \mathrm{MPa}$ and, in the treatment with highest salinity level $\left(12.5 \mathrm{dS} \mathrm{m}^{-1}\right)$, the osmotic potential was equal to $-1.24 \mathrm{MPa}$, causing a reduction of $113 \%$ (Figure 2 ).

There was no significant difference between the water sources with respect to plant water potential $(\mathrm{P}>0.05)$. The relationship of the water potential in the plant as a function of the EC of the treatments decreased linearly (Figure 2). The EC of $2.5 \mathrm{dS} \mathrm{m} \mathrm{m}^{-1}$ led to a value of $-0.53 \mathrm{MPa}$, a reduction of $37 \%$ in relation to the control, which led to $-0.38 \mathrm{MPa}$.

The EC values of 5, 7.5, 10 and $12.5 \mathrm{dS} \mathrm{m}^{-1}$ resulted in reductions of $60,70,80$ and $100 \%$, respectively, in relation to the control.

With the increase in soil EC and, consequently, in the concentration of the salts used in the composition of the irrigation water, there was a reduction in the total potential of the soil; this reduction of the soil potential increases the energy of retention of water in its pores, requiring the plant to also decrease its total potential in order to absorb water from the soil.

The linearity of this relationship was also found in studies conducted by Coelho et al. (2014), with cowpea subjected to saline stress. Bayuelo-Jiménez et al. (2003), working with various species of Phaseolus beans under saline stress, observed a decrease in the osmotic potential with the increment of salinity in all plants. Souza et al. (2011) also found reduction in the osmotic potential with the increment in the saline concentration of the substrate, decreasing from -0.61 to -0.73 $\mathrm{MPa}$ in cowpea plants.

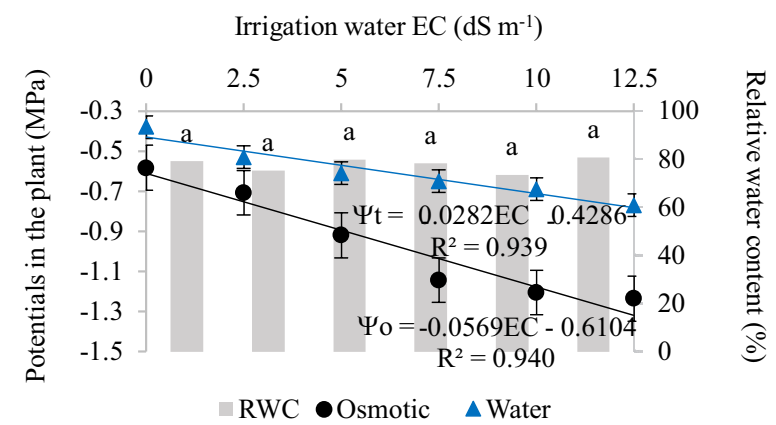

RWC CV\% = 9.88; Osmotic potential CV\% $=17.93$; Water potential CV\% $=26.77$

Figure 2. Relative water content (RWC) with the test of means, osmotic potential and water potential with their respective standard errors in the cowpea leaf as a function of the electrical conductivity in the irrigation water $(\mathrm{EC})$ at 35 days after planting, determined in the predawn hours
Considering the reduction of plant water potential with the increase in saline concentration, caused by the decrease in plant osmotic potential, it becomes evident the osmotic adjustment in these plants, either through the absorption of ions from the soil or the production of compatible osmolytes.

With the decrease in the osmotic potential of the leaf, there was an entry of water in the plant to maintain the physiological activities, causing the RWC to show no significant difference $(\mathrm{P}>0.05)$ (Figure 2).

These results show that the cowpea cultivar used in the experiment (IPA 206) was able to extract water at low soil water potentials, as in the case of $-0.98 \mathrm{MPa}$. Different results were reported by Shaheen et al. (2013), who observed decreases in RWC as a function of the increase in salinity, working with eggplant and analyzing RWC from 6 to 8 a.m. Such difference is due to the period of the measurements, since transpiration is more intense in the predawn hours of the morning than in the night.

In the period of determination of plant water potential (35 DAP), $\Psi$ atm varied from approximately -23 to $-25 \mathrm{MPa}$; despite being a low value compared with the mean of the night period, it is 30 times inferior to the lowest value of plant water potential, observed in the treatment of $12.5 \mathrm{dS} \mathrm{m}^{-1}(-0.77 \mathrm{MPa})$ (Figure 3).

Despite its importance, there is little information on the relationship between the loss of water during the night and the disequilibrium between soil and plant water potentials in the predawn hours (Bucci et al., 2004). The water potentials in the soil-plant-atmosphere system determine the movement of water in the plant and, as a result, influence the various physiological processes of the plants.

According to Katerji \& Hallaire (1984), during the predawn hours the water potential in the leaf expresses the equilibrium between the water potentials of the leaf and of the soil, or at least there is an expectation for the potential in the plant to come to equilibrium with the potential in the root zone (Caird et al., 2007). Actually, some studies find disequilibrium during the predawn hours between the water potentials in the plant and in the soil, with large magnitudes $(\geq 0.5 \mathrm{MPa})$, as observed by Donovan et al. (2001). The water potentials of soil, plant and atmosphere are shown in Figure 3.

None of the treatments achieved equilibrium between soil and plant potentials during the predawn hours. Only in the control treatment, these values were closer, with lower differences between them; in the other treatments, the difference between the means of soil and plant potentials was $-0.2 \pm 0.01 \mathrm{MPa}$, which evidences a disequilibrium of great magnitude, corroborating with the data of soil and plant water potentials.

The absence of variations in RWC values indicates that, at a certain moment, the water potential in the leaf was lower than in the soil, although at that moment the turgidity promoted a dilution of the solutes in the leaves, causing soil water potential to be lower and thus ceasing water absorption.

Only in the control treatment, the plant continued to absorb water from the soil during the predawn hours; since transpiration is minimal during the night and irrigations were performed in the late afternoon, the main responsible for the 
A

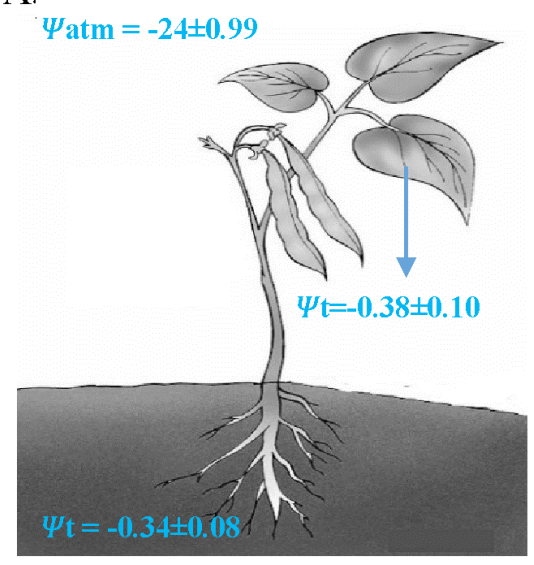

B.

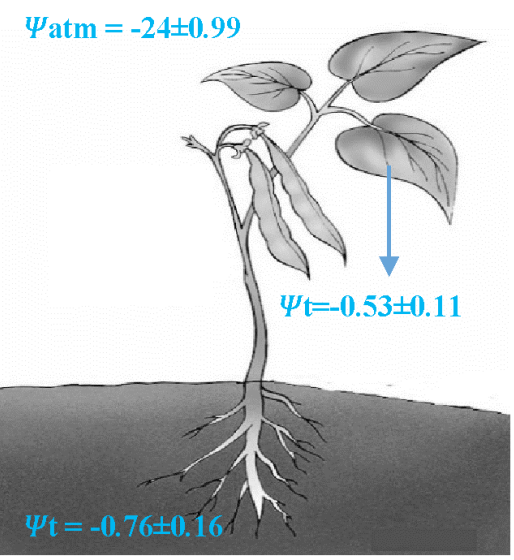

C.

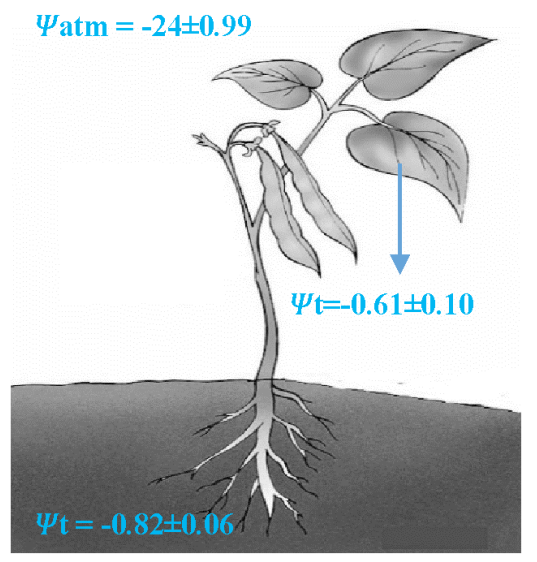

D. $\Psi$ atm $=-24 \pm 0.99$

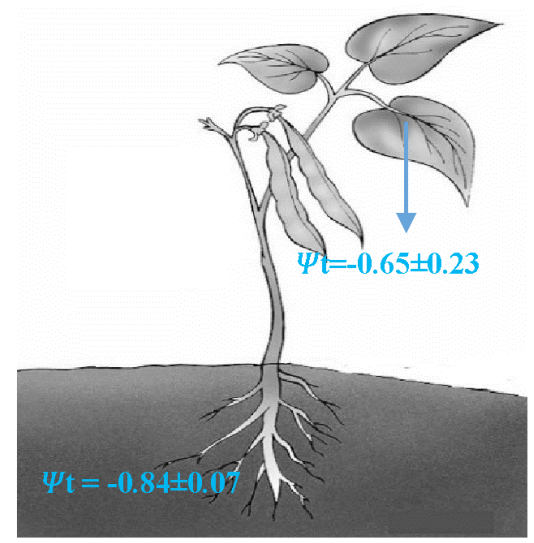

E.

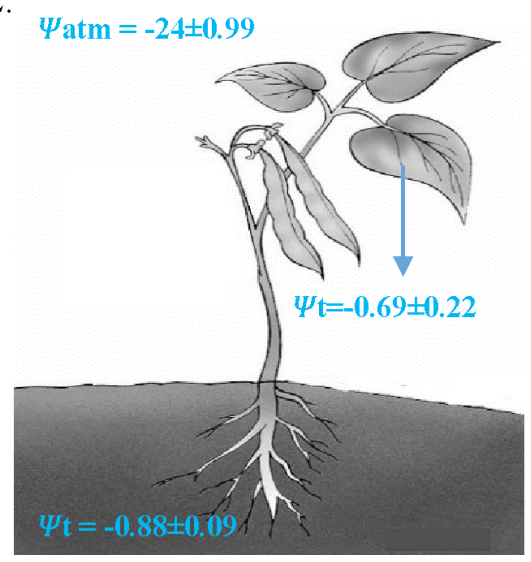

F.

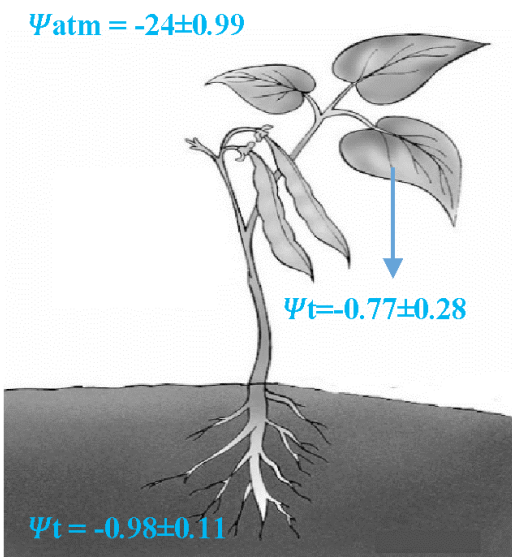

Figure 3. Water potentials (MPa) in the soil-plant-atmosphere system in cultivation of cowpea irrigated with saline water at 35 days after planting, determined in the predawn hours. (A) 0; (B) 2.5; (C) 5.0; (D) 7.5; (E) 10 and (F) $12.5 \mathrm{dS} \mathrm{m}^{-1}$

entry of water in the plant was the lowering of its osmotic potential. However, the occurrence of a higher potential in the plant, compared with the soil, is not justified by any mechanism.

Donovan et al. (2001) observed disequilibrium in the predawn hours between plant and soil water potentials in 16 of the 21 plant species tested. Donovan et al. (2003) also reported disequilibrium between plant and soil water potentials in plants from the genera Chrysothamnus and Sarcobatus. James et al. (2006), working with plants from the genus Sascorbatus under saline conditions, observed disequilibrium of great magnitude between the plant and the soil.

Yield data express in a better way the impact of the reduction of soil and plant water potentials due to the increase in irrigation water EC (Figure 4).

Considering a density of 50000 plants $\mathrm{ha}^{-1}$, the yield (measured in mass of grains per hectare) showed a drastic decrease already from the EC of $2.5 \mathrm{dS} \mathrm{m}^{-1}$ on, reducing from 800 to $193 \mathrm{~kg} \mathrm{ha}^{-1}$ (reduction of $\cong 75 \%$ ), while the EC of $5 \mathrm{dS}$ $\mathrm{m}^{-1}$ showed yield of $63 \mathrm{~kg} \mathrm{ha}^{-1}$ (reduction of $\cong 92 \%$ ) and the EC of $7.5 \mathrm{dS} \mathrm{m}^{-1}$ an yield of $9.5 \mathrm{~kg} \mathrm{ha}^{-1}$ (reduction of $\cong 99 \%$ ), i.e., the yield was highly influenced by the decrease in soil and plant water potentials.

Some authors also confirmed, working with the same cowpea cultivar (IPA 206), the interference of EC on its yield, with values lower than those obtained in the present study, such as Martins et al. (2003), with yield of $693 \mathrm{~kg} \mathrm{ha}^{-1}$. Dantas et al. (2002), considering the same plant density of the present

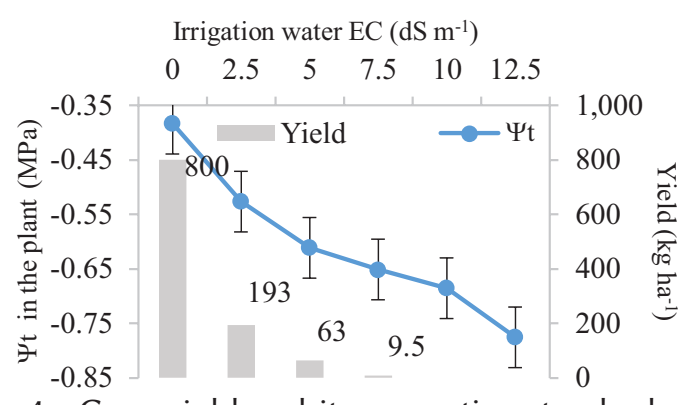

Figure 4. Crop yield and its respective standard error in cowpea plants cultivated with saline water, harvested from 38 to 60 days after planting as a function of the electrical conductivity of the irrigation water (EC) and with density of 50000 plants ha-1

study (50000 plants ha ${ }^{-1}$ ), under saline conditions, observed yields of 240, 123 and $60.5 \mathrm{~kg} \mathrm{ha}^{-1}$ for EC values of 3, 6 and 9 dS $\mathrm{m}^{-1}$, respectively.

\section{Conclusions}

1. The water sources used in the composition of the irrigation water did not differ significantly between the types of salts for the osmotic and water potentials of the soil and the plant.

2. The reduction in soil osmotic potential with the increase in irrigation water salinity was the main responsible for the decrease in the total water potential of the soil. 
3. There was no equilibrium between the water potentials of the soil or the plant during the predawn hours.

4. Irrigation water salinity of $2.5 \mathrm{dS} \mathrm{m}^{-1}$ limited cowpea production, favoring a reduction of approximately $75 \%$ in yield.

\section{ACKnowledgments}

The authors thank the National Council for Scientific and Technological Development (CNPq - Universal Call $\mathrm{n}^{\circ}$ 473817/2013-6), for the financial support, the Pernambuco Science and Technology Support Foundation (FACEPE), the Graduate Program in Agricultural Engineering of the UFRPE and its Pro-Rector of Research and Graduate Programs (PRPPG).

\section{Literature Cited}

Adolf, V. I.; Jacobsena, S.; Shabala, S. Salt tolerance mechanisms in quinoa (Chenopodium quinoa Willd.). Environmental and Experimental Botany, v.92, p.43-54, 2013. http://dx.doi. org/10.1016/j.envexpbot.2012.07.004

Ayers, R. S.; Westcot, D. W. A qualidade da água para irrigação. Campina Grande: UFPB, 1999. 153p.

Bayuelo-Jiménez, J. S.; Debouck, D. G.; Lynch, J. P. Growth, gas exchange, water relations, and ion composition of Phaseolus species grown under saline conditions. Field Crops Research, v.80, p.207-222, 2003. http://dx.doi.org/10.1016/S03784290(02)00179-X

Bucci, S. J.; Scholz, F. G.; Goldstein, G.; Meinzer, F. C.; Hinojosa, J. A.; Hoffmann, W. A.; Franco, A. C. Processes preventing nocturnal equilibration between leaf and soil water potential in tropical savanna woody species. Tree Physiology, v.24, p.1119-1127, 2004. http://dx.doi.org/10.1093/treephys/24.10.1119

Caird, M. A.; Richards, J. H.; Donovan, L. A. Nighttime stomatal conductance and transpiration in C3 and C4 plants. Plant Physiology, v.143, p.4-10, 2007. http://dx.doi.org/10.1104/ pp.106.092940

Coelho, J. B. M.; Barros, M. F. C.; Bezerra Neto, E.; Correa, M. M. Comportamento hídrico e crescimento do feijão vigna cultivado em solos salinizados. Revista Brasileira de Engenharia Agrícola e Ambiental, v.17, p.379-385, 2013. http://dx.doi.org/10.1590/ S1415-43662013000400004

Coelho, J. B. M.; Barros, M. F. C.; Bezerra Neto, E.; Souza, E. R. Ponto de murcha permanente fisiológico e potencial osmótico de feijão caupi cultivado em solos salinizados. Revista Brasileira de Engenharia Agrícola e Ambiental, v.18, p.708-713, 2014. http:// dx.doi.org/10.1590/S1415-43662014000700006

Dantas, J. P.; Marinho, F. J. L.; Ferreira, M. M. M.; Amorim, M. S. N.; Andrade, S. I. O.; Sales, A. L. Avaliação de genótipos de caupi sob salinidade. Revista Brasileira de Engenharia Agrícola e Ambiental, v.6, p.425-430, 2002. http://dx.doi.org/10.1590/ S1415-43662002000300008

Donovan, L.; Linton, M.; Richards, J. Predawn plant water potential does not necessarily equilibrate with soil water potential under well-watered conditions. Oecologia, v.129, p.328-335, 2001. http:// dx.doi.org/10.1007/s004420100738

Donovan, L. A.; Richards, J. H.; Linton, M. J. Magnitude and mechanisms of disequilibrium between predawn plant and soil water potentials. Ecology, v.84, p.463-470, 2003. http://dx.doi. org/10.1890/0012-9658(2003)084[0463:MAMODB]2.0.CO;2
EMBRAPA - Empresa Brasileira de Pesquisa Agropecuária. Manual de métodos de análises de solo. 2.ed. Rio de Janeiro: Ministério da Agricultura e do Abastecimento, 1997. 212p.

EMBRAPA - Empresa Brasileira de Pesquisa Agropecuária. Sistema brasileiro de classificação de solos. Rio de Janeiro: Centro Nacional de Pesquisa de Solos, 2013. 353p.

Gómez-Bellot, M. J.; Álvarez, S.; Bañón, S.; Ortuño, M. F.; SánchezBlanco, M. J. Physiological mechanisms involved in the recovery of euonymus and laurustinus subjected to saline waters. Agricultural Water Management, v.128, p.131-139, 2013. http://dx.doi. org/10.1016/j.agwat.2013.06.017

Grieve, C. M.; Grattan, S. R.; Maas, E. V. Plant salt tolerance. In: Wallender, W. W.; Tanji, K. K. (ed.) Agricultural salinity assessment and management. 2. ed. Roston: ASCE, Cap.13, 2012. p.405-459. ASCE Manual and Reports on Engineering n.71

IPA - Instituto Agronômico de Pernambuco. Manual de recomendação de adubação para o estado de Pernambuco: 2. aproximação. 2. ed. Recife: IPA, 2008. 212p.

James, J. J.; Alder, N. N.; Mühling, K. H.; Läuchli, A. E.; Shackel, K. A.; Donovan, L. A.; Richards, J. H. High apoplastic solute concentrations in leaves alter water relations of the halophytic shrub, Sarcobatus vermiculatus. Journal of Experimental Botany, v.57, p.139-147, 2006. http://dx.doi.org/10.1093/jxb/erj016

Katerji, N.; Hallaire, M. Les grandeurs de référence utilisables dans l'étude de l'alimentation en eau des cultures. Agronomie, v.4, p.999-1008, 1984. http://dx.doi.org/10.1051/agro:19841011

Lv, S.; Jiang, P.; Chen, X.; Fan, P.; Wang, X.; Li, Y. Multiple compartmentalization of sodium conferred salt tolerance in Salicornia europaea. Plant Physiology and Biochemistry, v.51, p.47-52, 2012. http://dx.doi.org/10.1016/j.plaphy.2011.10.015

Martins, L. M. V.; Xavier, G. R.; Rangel, F. W.; Ribeiro, J. R. A.; Neves, M. C. P.; Morgado, L. B.; Rumjanek, N. G. Contribution of biological nitrogen fixation to cowpea: A strategy for improving grain yield in the semi-arid region of Brazil. Biology and Fertility of Soils, v.38, p.333-339, 2003.

Melo, H. F.; Souza, E. R.; Almeida, B. G.; Freire, M. B. G. S.; Maia, F. E. Growth, biomass roduction and ions accumulation in Atriplex nummularia Lindl grown under abiotic stress. Revista Brasileira de Engenharia Agrícola e Ambiental, v.20, p.144-151, 2016. http:// dx.doi.org/10.1590/1807-1929/agriambi.v20n2p144-151

Nascimento, S. P.; Bastos, E. A.; Araújo, E. C.; Freire Filho, F. R.; Silva, E. M. Tolerância ao déficit hídrico em genótipos de feijão-caupi. Revista Brasileira de Engenharia Agrícola e Ambiental, v.15, p.853860, 2011. http://dx.doi.org/10.1590/S1415-43662011000800013

Razzaghi, F.; Ahmadi, S. H.; Adolf, V. I.; Jensen, C. R.; Jacobsen, S. E.; Andersen, M. N. Water relations and transpiration of quinoa (Chenopodium quinoa Willd.) under salinity and soil drying. Journal of Agronomy and Crop Science, v.197, p.348-360, 2011. http://dx.doi.org/10.1111/j.1439-037X.2011.00473.x

Rengasamy, P. World salinization with emphasis on Australia. Journal of Experimental Botany, v.57, p.1017-1023. 2006. http://dx.doi. org/10.1093/jxb/erj108

Richards, L. A. Diagnosis and improvement of saline and alkali soils. Washington: US Department of Agriculture, 1954. 160p. USDA Agricultural Handbook, 60 
Shaheen, S.; Naseer, S.; Ashraf, M.; Akram, N. A. Salt stress affects water relations, photosynthesis, and oxidative defense mechanisms in Solanum melongena L. Journal of Plant Interactions, v.8, p.8596, 2013. http://dx.doi.org/10.1080/17429145.2012.718376

Slatyer, R. O. Plant-water relationships. New York: Academic Press, 1967. 378p.

Souza, E. R.; Freire, M. B. G. S.; Cunha, K. P. V.; Nascimento, C. W. A.; Ruiz, H. U.; Lins, C. M. T. Biomass, anatomical changes and osmotic potential in Atriplex nummularia Lindl. cultivated in sodic saline soil under water stress. Environmental and Experimental Botany, v.82, p.20-27, 2012. http://dx.doi. org/10.1016/j.envexpbot.2012.03.007
Souza, E. R.; Freire, M. B. G. S.; Melo, D. V. M.; Montenegro, A. A. A. Management of Atriplex nummularia Lindl. in a salt affected soil in a semi arid region of Brazil. International Journal of Phytoremediation, v.16, p.73-85, 2014. http://dx.doi.org/10.108 0/15226514.2012.759529

Souza, R. P.; Machado, E. C.; Silveira, J. A. G.; Ribeiro, R. V. Fotossíntese e acúmulo de solutos em feijoeiro caupi submetido à salinidade. Pesquisa Agropecuária Brasileira, v.46, p.586-592, 2011. http://dx.doi.org/10.1590/S0100-204X2011000600003

Thomas, G. W. Exchangeable cations. In: Methods of soil analysis. Part-2 Chemical methods. Madison: American Society of Agronomy, 1982. p.159-165. 